\title{
RIGHTS, LIBERTIES, FREEDOMS
}

\section{J. FRIEDRICH $\dagger$}

Bills of rights, civil liberties, human freedoms-they all are attempts to state and describe in broad outline the general principles that are to govern the relation between the individual and the community, i. e., the government. The forms in which this has been done are very numerous. Their bearing upon an emerging federalism is evidently of the very greatest importance. ${ }^{1}$

While it is still customary to talk of a "bill of rights" actually this terminology is definitely out of date. In the I8th century, rights were thought of as "immutable", "inalienable", "natural". The idea of such individual rights was part of the cult of rationalism and individualism which characterized the "Heavenly City of the eighteenth century philosophers". ${ }^{2}$

In the course of the nineteenth century it became increasingly clear that such rights were not something absolute and unchangeable. As the rationalist beliefs of the I8th century appeared more and more in historical perspective, rights were seen as constitutionally created and guaranteed. They varied from time to time and from country to country. Amendments to the American and other constitutions brought home to all who were blinded by dogmatic prejudice that these "rights" were really "civil liberties"-a constitutionally guaranteed and reserved sphere of individual liberty.

But even this concept in turn declined. The constitution became the bulwark of vested interests; progressive forces looked for a symbol which would indicate their preoccupation with the needs of the working man, rather than the requirements of the economically privileged. It became a matter of freedom for the individual to be an equal member of the community.

To these three stages in the evolution of thought on the subject of the relation of the individual to the community and its government correspond significant shifts in emphasis as to what is most important for the individual. In the period in which natural rights were the forms of interest, property was seen as the key to the individual's independence. It was felt by Locke and the whole movement of which he

$\dagger$ Ph. D., I925, University of Heidelberg; Professor of Political Science in Harvard University; author of THE NEW BELIEF IN THE CoMmon MAN (I942), and other works in the field of Political Science.

I. Cf. Frienrice, Constitutional Government and Democracy (i94I), The New BeLIEF IN THE CoMmon MAN (1942). See also Brecht, European Federation and the Democratic Alternative (I942) 55 HARv. L. REv. 563.

2. Becker, The Heavenly City of the I8th Century Philosophers (1933). 
was the most persuasive exponent that the individual's right to the fruits of his labor could be most effectively protected by protecting his property. With this went the cheerful assumption that anyone who wanted to work, could, and that anyone who did work was likely to accumulate property, if he was thrifty.

In the period in which civil liberties came into the foreground of attention (none of these periods, can, of course, be rigidly delimited), the activities of the individual as a person and as a citizen featured most prominently. Freedom of speech and of assembly and freedom of the press seem to have preoccupied most thought in the field. Besides these, freedom of association, particularly as exemplified in the trade unions, became an urgent concern. It seemed vital to have these freedoms of expression effectively protected, if a community was to be governed by the people, that is to say citizens who judged and acted "freely".

But as the "individual", in the 2oth century, was seen more and more as the victim of social "forces" over which he had little or no control, the problem assumed new forms. It was now no longer a matter of allowing the individual freedom of expression; for what was the use of such freedoms, if he could not "live"? The "freedom to starve" became the cynical expression of a new ferment, the constructive side of which is expressed in President Roosevelt's famous two freedoms: freedom from want and freedom from fear. Both these freedoms, while undoubtedly priceless to the individual, are patently dependent upon governmental action: the freedom from fear obviously calls for action on a world-wide basis. But freedom from want, it will be recognized by anybody who understands the modern economy, likewise depends upon world-wide cooperation. It is clear, therefore, that existing governments are increasingly incapable of handling the problems which the relation of the individual to the community raises in the modern world. Attempts to deal with these problems lead directly into the issues of world organization and world federalism with which we are so much concerned today. ${ }^{3}$

It is important to emphasize this fact in connection with any discussion of the "bill of rights" as applied to world federalism because the older, outworn (yet still surviving) views on "bills of right" tend to see them as primarily "interferences" with the government, and hence as weakening it. In truth, both the civil liberty conception and

3. The author does not wish to imply by the use of the word "world", that such an organization must be all-inclusive at the outset. Any federal system that includes a sufficient number of former national "states", say one quarter of the globe, would seem to qualify as a world organization, particularly if it extends over more than one continent. 
the civic freedom conception are based upon an almost diametrically opposite view: they seek to strengthen the individual and his contribution to the community through collective action and thereby strengthen the community itself.

Certainly a "bill of rights" of a world federalism must be seen in such a light. It grows out of the question: what provisions should the constitution contain to elicit the maximum contribution from all individuals comprised under the constitution? To transpose the President's formula, the answer might be: they must be free to express themselves in matters of conscience and of communal concern; but in order to do this effectively they must be free from want, and they must be free from fear.

The latter requirement has, of course, been recognized in English speaking countries for a long time in a form the President did not mention: the right not to be arrested and seized-habeas corpus-is one of the most ancient and jealously guarded rights of Americans and Englishmen. But recent events have made it increasingly apparent that this guarantee against arbitrary arrests and seizures, while enormously important, is not sufficient. There is also the collective danger and fear arising from wanton aggression of an outside foe. To guarantee that freedom definitive action in the international sphere is called for. As the President himself put it: "It means a world-wide reduction in armaments to such a point and in such a thorough fashion that no nation will be in a position to commit an act of physical aggression against any neighbor, anywhere in the world"."

Whatever view one takes of that matter, it is clear that we are here face to face with forces which are clearly beyond the ken of the individual. That is even more true, perhaps, of the freedom from want. To many, an unprecedented optimism is implicit in the guarantee of a freedom from want. For "can we actually cope with want?" Is the road leading away from want clear and distinctive? Our American aspirations have found eloquent expression in speeches of political leaders, such as Vice-President Wallace. ${ }^{5}$ Are we not here confronted with a problem belonging to an entirely different order than the freedom of expression? When we speak of freedom from want, we are proposing to give to people something they have not got, rather than restraining others from taking from them what they presumably wish to use! Moreover, freedom from want presents problems largely in

4. Message to Congress on the State of the Union, January 6, I94r. This, it should be noted, is too limited a conception of the freedom from fear; the rights involved in habeas corpus are, it would seem, essential to any democratic federalism. 1942 .

5. Hon. Henry A. Wallace, Address before the Free World Association, May 8, 
the material realm. It is the age-old problem of poverty. There is a psychological aspect to it, of course; people's needs and satisfactions vary greatly in accordance with a consumption pattern to which they are accustomed, but even this pattern is again a material thing. It cannot be gainsaid, therefore, that freedom from want is something beyond human will to the extent to which it is subject to the laws and limitations of the material world. ${ }^{6}$

However, the President offered certain specifications for this freedom. It may be well to examine further what he said concerning the freedom from want. Translated into world terms, he stated, it means economic understandings which will secure to every nation a healthy peacetime life for its inhabitants everywhere in the world. In other words, he elaborated it in terms of free trade rather than in terms of social security legislation and the right to work. Yet the latter undertakings appear to be much more central to the achievement of freedom from want than free trade. One cannot help feeling that it was the conservative free trade thought of the State Department which had worked out this interpretation.

It should be noted, however, that the expression "understanding" which the President used allowed considerable latitude. This is important when we recollect that the Atlantic charter specifically provided in point five that the signatories (now all the United Nations) "desire to bring about the fullest collaboration between all nations in the economic field with the object of securing, for all, improved labor standards, economic adjustment and social security". It should be noted that at a recent meeting of the International Labor Office in October I94I, attended by representatives of 35 nations, these social and economic principles were endorsed.

Even the guarantee of the right to work is, however, insufficient in large areas of the world. The economically backward regions, such as India and China, cannot hope to see the lot of their starving peasantry alleviated by either free trade or the right to work. For the fact is that those millions of tillers of the soil are overworked and exploited. Freedom from want for those people calls for undertakings similar to agricultural legislation in the advanced countries: Switzerland, Denmark, Australia, and the United States. In other words, the right to work can be made meaningful only if related to effective use of the means of production. If these areas are not to adopt the social system of large collective farms, the right to control those things which a man needs to control to enjoy the fruits of his labor, more especially farms,

6. See economic section of forthcoming volume entitled, The Comma STrucrure of WorLd Government, edited by George Benson, Russell H. Ewing, Howard Eaton and others. 
land and stock, will have to be recognized. This is a gigantic undertaking, when one considers the systems of exploitation and chicanery combined with outmoded methods of production that have been prevalant in many of these lands. It will call for a patient building up of widely dispersed capital resources. Obviously all a federation could do would be to insure the political and administrative conditions requisite for steady progress.

Returning now to freedom from fear what would seem to be called for is a federal police force and a federal military establishment. Unless some such central force is effectively built up, no chance exists of guaranteeing even a minimum of freedom from fear within the territories of the federation or against external enemies. As Cordell Hull put it on July 23, I942: "It is plain that some international agency must be created which can-by force if necessary-keep the peace among nations in the future". It would be reckless to claim that freedom from fear is an accomplished fact in the United States. We have our third degree, lynchings, and labor baiting; yet, after all is said and done, the United States citizen is "freer from fear" than the terrorized subject of dictatorial regimes. It is therefore not too much to say that the achievement of conditions approximating those prevailing in the United States today would represent substantial progress, at least for quite a few of the members of the federation. This would be even more true of freedom from external aggression. The United States would never have been able to defend herself the way she has without a national military establishment. State militias have been a welcome addition, and probably will be in a world federalism, but the supreme command needs to be lodged in the federation itself. The organizational problem involved will be on the way toward solution as a result of merging the military command in the United Nations, especially among the United States, the Netherlands, Great Britain and the Dominions, as was the case previously when federal systems were forming in the United States, Switzerland, and Germany. For all these federations were created after wars which had brought about the unification of military organization. ${ }^{7}$

More baffling than either the problems of freedom from want or freedom from fear are those of the freedom of expression and religion. Here the difficulties are political and spiritual. The bloody wars of religion preceded the recognition of religious toleration in Europe. The positive acceptance of other men's beliefs is difficult in

7. Ibid., section on military organization. See also WRIGHT, REPORT to COMAIISstow for the Study of Organization of Peace, and Bonnet, The United Nations (1942). 
inverse proportion to the ardor with which a particular faith is held to be "the truth". It is easy for the agnostic to be tolerant of other men's religions; he looks upon them as mild cases of mental immaturity and lets it go at that. It is supremely difficult for the man passionately concerned with the welfare of the soul to tolerate views which he is convinced corrupt the soul, but that is the position of the majority of mankind today. Since the freedom of religion is the basis and the starting point of other freedoms of expression, the problem is quite central. India with her conflict between Hindus and Moslems illustrates the tremendous obstacles which such clash of religious faiths can create. When we reflect on the vital part free education plays in the maintenance and development of free institutions and how intimately education is linked with religious beliefs and ecclesiastical organization, we glimpse the magnitude of the problem confronting us. At first we may have to be content with something much more limited and general than the separation of church and state which we deem essential to religious freedom, something far short of freedom of the press and of assembly as we have come to practice them in the United States.

There is no object in our becoming "ideological imperialists". We cannot erect a democratic world order upon a set of ideas which we impose upon unwilling peoples by the force of arms, the pressure of financial aid, or even by the supply of food. The success of the enterprise of world federation depends upon the free and voluntary acceptance of the principles involved by all those peoples who would enter such a world federation. It is impracticable for us to think in terms of ideas which are only acceptable to us. Just as the original Bill of Rights was adopted by regular constitutional amendment under the Constitution, so a similar bill for a supra-national federation should be adopted by common consent.

It is impossible to claim that a world federation will guarantee the "four freedoms" in the sense that it would insure their enforcement; even the American federal Union has been unable to do that. As we have stated already, at least one of these freedoms is conditioned by our "power over nature", our ability to master material limitations, but federalism would seem to hold out a better prospect of effectively guaranteeing such freedoms than any other plan. Federalism provides the tried pattern of constitutional government for large areas, and an effective guarantee of rights or personal freedoms presupposes constitutional government.

It is difficult now to say what principles would be generally accepted. In discussing the problem recently, in The New Belief in the Common Man, I wrote: 
"Eighty million Germans, a hundred and fifty million Russians, tens of millions of other Slavic peoples, well over two hundred million Indians, between four and five hundred million Chinese and Japanese, not to speak of the numerous other peoples in the Near and the Far East, in all probably three fourths of the earth's population, have been living under social and political conditions where freedom of speech, of the press, and of assembly are almost meaningless phrases.

And as for freedom of religion-and of education? Do not many of these people acknowledge faith in a religion which dogmatically denies the desirability of tolerating other creeds? Can we force them to accept toleration?" 8

The worst of it is that we ourselves are far from having accepted the job of becoming world citizens. We need a good deal more than tolerance. The situation calls for positive steps. What are the common ethical aspirations of mankind? Are there certain basic patterns of behavior that are common to the vast majority of mankind, whether they be Christians or Buddhists, Mohammedans or Jews, Confucians or secular humanists? Some have maintained that there are; but unlike the natural law writers of the past, they have based their views upon a comparison of actual moral and ethical beliefs expounded and fostered by the great world religions. William E. Hocking in his Living Religions and a World Faith has expressed the view that there are supreme values embodied in each of the world's great religions which represent contributions to an emergent "world faith". He has painted a broad and catholic canvas. Irving Babbitt and the group of writers known as the neo-humanists groped for factual support for their assumption of such universal ethical principles. Professor Arnold Toynbee, whose far-ranging scholarship found striking expression in his $A$ Study of History, stated it at least as a hope, resulting from his comparison of all the great religions, that religious elements in Islam, Hinduism, Buddhism, as well as Christianity may provide the basis for such a pan-human ethos. "There can be no international ethos without a religious basis", he wrote.

The difficulty with all these interpretations is, as stated previously, that they are essentially the product of Western minds. Moreover, they are the products of Western minds somewhat removed from the thought and feeling of ecclesiastical rigidity. Such explorations are worthwhile, indeed, but they cannot from a democratic standpoint be considered as more than preliminary. Something more representative is needed. We must discover what the representatives of the great world religions would actually accept as sound from their respective 
viewpoints. In The New Belief in the Common Man I raised the question in concrete terms: "Might we not gather forthwith a world convention of men and women of thought rather than action who could represent a majority of mankind?". No world federalism should be attempted without such a preliminary canvass of basic beliefs. We are not going to achieve a unity of beliefs. There is no possibility of an agreement on fundamentals, but we may well discover common modes of behavior resulting from different fundamental views. There are striking hints of such common concerns. The Confucians, e. g., envisaged the coming of universal peace just as much as the Christians and the Jews; they called it the Great Harmony.

Around such concerns, and directed toward them, might be grouped such principles of conduct as find a basis in the ethical convictions of a majority of mankind. We would seek particularly to discover principles of conduct which would delineate the proper relationship between the individual (or the family) and the community at large: the local, regional, national, and world-wide authorities of government. It seems impossible at this time to insist upon specific conclusions to which such a "parliament of man" may come, but it should be noted that all the great religions have a common belief in ethics as such. Implying the recognition of personal responsibility, such a belief posits an elemental realm of freedom: a right of each man to seek right and wrong. Thus the guess might be hazarded that such a pan-humanist congress would recognize personal responsibility and religious freedom in the broad sense.

But how can there be personal responsibility without a minimum of personal independence? Protection of its citizens against arbitrary searches and seizures or against being detained without being charged with a legally determinate crime would seem to be implied as a necessary task of the world federation. Without this protection the federal world government could not hope to secure the essential support of its citizen. There might be troublesome breakdowns similar to the failure of our Southern States to provide such personal independence for the negro; but as a general principle of conduct, the world congress might well accept it. If local (national) authorities proved unable to secure this type of protection for the world citizen, they should probably forfeit the right to continue in office. This would provide us, if accepted by the world congress, with the quintessence of freedom from fear.

It seems less likely that ready agreement could be secured upon principles of conduct consonant with the freedom from want and the freedom of expression, but speculation here is fraught with difficulties 
because of the many different views which must be considered. Nevertheless, the answers should be democratically determined. If, therefore, such a world convention or "parliament of man" cannot be assembled to seek out the answers, it would, in the light of the foregoing, seem highly desirable to do as the makers of our constitution did: first, set up a working frame; then adopt as amendments the common views and traditions acceptable to a majority concerning the relationship between the individual and the world federation. Obviously, the very size of the organization necessitates our conceiving of these in the broadest terms in order that these principles may fit the widely varying conditions in member states. It also demands that we do not thoughtlessly insist that our own principles are necessarily the most urgently important ones. The Confucians' insistence upon the family may be sounder as a principle of world citizenship than our own atomistic individualism. It may-and yet it may not. As philosophers we may argue this point for many a day; as world citizens we will accept that principle which seems most satisfactory to most men. The naturalists were right when they stressed the fact of common elements in human nature; the positivists were sound when they, like Bentham, insisted that the only way to discover these common elements is through the process of free discussion and independent voting. It is upon that basis that a world-wide bill of rights, or civil liberties, or a charter of world freedom will rest securely. 